\title{
Lysophosphatidic Acid Stimulates Neurotransmitter-Like Conductance Changes that Precede GABA and L-Glutamate in Early, Presumptive Cortical Neuroblasts
}

\author{
Adrienne E. Dubin, ${ }^{1,2}$ Tristram Bahnson,, ${ }^{1,2}$ Joshua A. Weiner, ${ }^{1,3}$ Nobuyuki Fukushima, ${ }^{1}$ and Jerold Chun ${ }^{1,4}$ \\ ${ }^{1}$ The Department of Pharmacology, ${ }^{2}$ The Department of Medicine, ${ }^{3}$ Neurosciences Graduate Program, and \\ ${ }^{4}$ Neurosciences and Biomedical Sciences Graduate Programs, School of Medicine, University of California, San Diego, \\ California 92093-0636
}

During neurogenesis in the embryonic cerebral cortex, the classical neurotransmitters GABA and L-glutamate stimulate ionic conductance changes in ventricular zone (VZ) neuroblasts. Lysophosphatidic acid (LPA) is a bioactive phospholipid producing myriad effects on cells including alterations in membrane conductances (for review, see Moolenaar et al., 1995). Developmental expression patterns of its first cloned receptor gene, Ip ${ }_{\mathrm{A} 1} / \mathrm{vzg}-1$ (Hecht et al., 1996; Fukushima et al., 1998) in the VZ suggested that functional LPA receptors were synthesized at these early times, and thus, LPA could be an earlier stimulus to VZ cells than the neurotransmitters GABA and L-glutamate. To address this possibility, primary cultures of electrically coupled, presumptive cortical neuroblast clusters were identified by age, morphology, electrophysiological profile, BrdU incorporation, and nestin immunostaining. Single cells from cortical neuroblast cell lines were also examined. Whole-cell variation of the patch-clamp technique was used to record from nestin- immunoreactive cells after stimulation by local administration of ligands. After initial plating at embryonic day 11 (E11), cells responded only to LPA but not to GABA or L-glutamate. Continued growth in culture for up to $12 \mathrm{hr}$ produced more LPAresponsive cells, but also a growing population of GABA- or L-glutamate-responsive cells. Cultures from E12 embryos showed LPA as well as GABA and L-glutamate responses, with LPA-responsive cells still representing a majority. Overall, $>50 \%$ of cells responded to LPA with depolarization mediated by either chloride or nonselective cation conductances. These data implicate LPA as the earliest reported extracellular stimulus of ionic conductance changes for cortical neuroblasts and provide evidence for LPA as a novel, physiological component in CNS development.

Key words: lysophosphatidic acid; LPA; chloride currents; cation currents; cerebral cortex; embryonic development; lysophospholipids; programmed cell death
The mammalian cerebral cortex consists of six neuronal layers that are produced over a discrete period of embryonic development (Angevine and Sidman, 1961). Neurons destined for a cortical layer are formed in a proliferative, neurogenic region overlying the lateral ventricles, thus called the "ventricular zone" (VZ; Boulder Committee, 1970). Previous studies examining the role of extracellular signaling molecules on cortical neurogenesis implicated two general families of receptor-mediated signals. Peptide growth factors acting through receptor tyrosine kinases have been shown in primary cell culture to influence the blastprecursor potential of cortical neuroblasts through responses that include both cell proliferation (through basic fibroblast growth factor) and differentiation (neurotrophin 3; NT3) (Temple and Qian, 1995). By comparison, physiological studies have revealed putative neuroblast ionotropic responses to GABA or L-glutamate, mediated by their cognate ligand-gated ion channels;

\footnotetext{
Received August 5, 1998; revised Dec. 4, 1998; accepted Dec. 4, 1998.

This work was supported by the National Institute of Mental Health, an institutional grant from the Howard Hughes Medical Institute, the James H. Chun Memorial Fund (J.C.), and National Institutes of Health (A.E.D., T.B.). We thank Drs. V. Dionne and M. Pompeiano for reading this manuscript.

Correspondence should be addressed to Dr. Chun, The Department of Pharmacology, School of Medicine, University of California, San Diego, 9500 Gilman Drive, La Jolla, CA 92093-0636.

Dr. Dubin's present address: RW Johnson PRI, 3535 General Atomics Court, Suite 100, San Diego, CA 92121.

Dr. Bahnson's present address: Division of Cardiology, Duke University Medical Center, Box 2959, Durham, NC 27710.

Copyright (C) 1999 Society for Neuroscience $\quad 0270-6474 / 99 / 191371-11 \$ 05.00 / 0$
}

these ionic changes have been suggested to influence the proliferative capacity of a stimulated blast by decreasing DNA synthesis (LoTurco et al., 1995; Owens et al., 1996). In addition to these interactions, however, it is likely that other forms of extracellular signals also exist, based in part on the normal cortical phenotype of null mutations for neurotrophins and/or their tyrosine kinase receptors, e.g., for NT3/trk receptors (Klein et al., 1993; Ernfors et al., 1994; Fariñas et al., 1994; Klein et al., 1994; Smeyne et al., 1994), or the requirement for serum and/or membrane fractions for the growth of cortical neuroblasts in culture (Kilpatrick and Bartlett, 1993; Temple and Davis, 1994; Temple and Qian, 1995).

To identify new extracellular signaling receptors expressed in the VZ, an approach was taken that combined degenerate PCR for G-protein coupled receptor (GPCR) genes with in situ hybridization; this approach allowed the identification of ventricular zone gene-1 (vzg-1), which has an expression pattern restricted to the cortical VZ during neurogenesis (Hecht et al., 1996). Functional analysis of the receptor led to the identification of a ligand; $v z g-1$ encodes a receptor for the bioactive lipid lysophosphatidic acid (LPA) and was thus redesignated lysophospholipid receptor A1 $\left(l p_{\mathrm{A} 1}\right)$, the first of a growing family of related lysophospholipid receptors (Hecht et al., 1996; Fukushima et al., 1998; Chun et al., 1999; Zhang et al., 1999). Documented cellular responses to LPA in cell lines from different lineages include cell proliferation; actin-based morphological changes involved in the formation of stress fibers in fibroblasts, neurite retraction, and rounding of cells in neuroblastoma cell lines (Moolenaar, 1995); gap-junction clo- 
sure (e.g., in WB cells; Hill et al., 1994); and increases in chloride $\left(\mathrm{Cl}^{-}\right)$conductances (e.g., in Rat-1 fibroblasts; Postma et al., 1996). Operation of this signaling system would represent a stimulus distinct from those previously described in the developing cerebral cortex by being (1) mediated by an extracellular lipid molecule and (2) transduced by a GPCR. The developmental expression pattern of $l p_{\mathrm{A} 1} / v z g-1$ predicted that extracellular LPA signaling could affect embryonic cortical neuroblasts. Here we report that LPA is indeed a major extracellullar stimulus for cortical neuroblasts, activating two distinct ionic conductances that cause depolarization and developmentally precede GABA and L-glutamate signaling.

\section{MATERIALS AND METHODS}

Primary cultures. All animal protocols were approved by the University of California, San Diego Animal Subjects Committee and are in accordance with National Institutes of Health guidelines and public law. Timedpregnant Balb/c mice [day of plug, embryonic day 0 (E0)] were euthanized by cervical dislocation, and embryonic cortical regions were dissected as described previously (Chun and Jaenisch, 1996) in cold serumfree OptiMEM-I (Life Technologies, Gaithersburg, MD) supplemented with $20 \mathrm{~mm}$ D-glucose, $1 \%$ penicillin-streptomycin, either with or without $55 \mu \mathrm{M} \beta$-mercaptoethanol. Cortices were triturated using a sterile long-nose Pasteur pipette into small clusters $(<50$ cells) and plated at a density of $\sim 10,000-50,000$ cells/12 mm coverslip previously coated with Cell-Tak (Collaborative Research, Bedford, MA). Cultures were grown at $37^{\circ} \mathrm{C}$ and $5 \% \mathrm{CO}_{2}$. Cells in clusters appeared healthy and remained proliferative $(87 \%$ incorporated BrdU at over the first $24 \mathrm{hr}$ within clusters), consistent with previous reports of rodent cortical cultures (Ghosh and Greenberg, 1995). The basic morphology of cells in clusters did not change over the duration of the experiment, whereas single cells more often appeared to differentiate into neurons with large sodium currents, although some single cells appeared to remain undifferentiated. The most responsive cells appeared to be those maintained in lowdensity cultures that resided within the clusters, and electrophysiology was performed on cells within small clusters.

Electrophysiology. The whole-cell patch-clamp technique (Hamill et al., 1981) was used to record ligand-induced currents from embryonic VZ cells maintained for 1-20 hr in serum-free media. Cells were visualized using a Nikon Diaphot 300 with DIC Nomarski optics. Cells were continuously perfused in a physiological saline $(\sim 0.5 \mathrm{ml} / \mathrm{min})$ unless otherwise indicated. The standard physiological saline (Tyrode's solution) contained (in $\mathrm{mm}$ ): $130 \mathrm{NaCl}, 4 \mathrm{KCl}, 5 \mathrm{CaCl}_{2}, 1.2 \mathrm{MgCl}_{2}$, and 10 hemi-Na-HEPES ( $\mathrm{pH}$ 7.37, 295-300 mOsm as measured using a Wescor 5500 vapor-pressure osmometer; Wescor, Logan, UT). In some experiments, the $\mathrm{Ca}^{2+}$ concentration of the physiological saline was decreased to $1 \mathrm{~mm}$, and similar results were obtained. Recording electrodes were fabricated from borosilicate capillary tubing (BF100; Sutter Instrument Co., Novato, CA), the tips were coated with dental periphery wax (Miles Laboratories, South Bend, IN), and had resistances of 8-15 M $\Omega$ when containing intracellular saline [in mM: $100 \mathrm{~K}$-gluconate, $25 \mathrm{KCl}, 0.483$ $\mathrm{CaCl}_{2}, 3 \mathrm{MgCl}_{2}, 10$ hemi-Na-HEPES, and $1 \mathrm{~K}_{4}$-BAPTA (100 nm free $\left.\mathrm{Ca}^{2+}\right), \mathrm{pH} 7.4$, with dextrose added to achieve $290 \mathrm{mOsm}$ ]. Series resistances $\left(R_{\mathrm{s}}\right)$ were $20-40 \mathrm{M} \Omega$. To mark cells that had been physiologically recorded, lysine-fixable rhodamine dextran $(10 \mathrm{kDa}$; Molecular Probes, Eugene, OR) was included at $500 \mu \mathrm{M}$ in the pipette solution. To determine the TTX sensitivity of voltage-activated inward currents, a $\mathrm{Cs}^{+}$-based intracellular saline was used to block outward $\mathrm{K}^{+}$currents (in mM): $25 \mathrm{CsCl}, 102.5$ methansulfonate, $0.483 \mathrm{CaCl}_{2}, 3 \mathrm{MgCl}_{2}, 10$ hemi-Na HEPES, and 1 BAPTA free acid, $\mathrm{pH} 7.4$ with $\mathrm{CsOH}$. In $\mathrm{Cl}^{-}$ ion substitution experiments, the cells were continuously perfused with low $\mathrm{Cl}^{-}$extracellular saline composed of (in $\mathrm{mm}$ ): $140 \mathrm{Na}$-isethionate, 3 $\mathrm{K}$-gluconate, $5 \mathrm{Ca}^{2+}$-acetate, $1 \mathrm{MgCl}_{2}$, and 10 hemi-Na-HEPES (305 mOsm, $\mathrm{pH}$ 7.37, with acetic acid). In experiments designed to shift the reversal potential $\left(V_{\text {rev }}\right)$ of nonselective cation (NSC) currents, an intracellular saline containing impermeant cations (ZIS) was used (Delay et al., 1997) [in mM: $100 \mathrm{NMDG}, 100$ methanesulfonate, $5 \mathrm{NaCl}, 1 \mathrm{BAPTA}$ free acid, $0.483 \mathrm{CaCl}_{2}\left(100 \mathrm{~nm}\right.$ free $\left.\mathrm{Ca}^{2+}\right), 2 \mathrm{MgCl}_{2}, 10$ hemi-NaHEPES; pH 7.4, with dextrose added to achieve $290 \mathrm{mOsm}]$. Liquid junction potentials were $-18 \mathrm{mV}$ using standard pipette and bath solutions as determined both empirically and using the computer program JPCalc (Barry, 1994); in the low $\mathrm{Cl}^{-}$extracellular saline, voltages were corrected by $+3 \mathrm{mV}$, and in experiments using ZIS and Tyrode's, voltages were corrected by $-15 \mathrm{mV}$. All voltages shown are corrected for liquid junction potential. Current and voltage signals were detected and filtered at $5 \mathrm{kHz}$ with an Axopatch 200A patch-clamp amplifier (Axon Instruments, Foster City, CA), digitally recorded with a TL-1 DMA laboratory interface (Axon Instruments) and personal computercompatible system, and stored on magnetic disk for off-line analysis. Data acquisition and analysis were performed with pClamp software. Slow changes in holding current were detected and filtered at $5 \mathrm{kHz}$ and recorded with a LPF200A DC amplifier (Warner, Hamden, CT) and VR-10B digital data recorder (Instrutech, Great Neck, NY) onto video tape. The signal was later analyzed at $10 \mathrm{~Hz}$ using Axotape software.

The total membrane capacitance $\left(C_{\mathrm{m}}\right)$ was determined as the difference between the maximum current after a $30 \mathrm{mV}$ hyperpolarizing voltage ramp from $-68 \mathrm{mV}$ generated at a rate of $10 \mathrm{mV} / \mathrm{msec}$ and the steady-state current at the final potential $\left(-98 \mathrm{mV}\right.$ ) (values refer to $V_{\mathrm{m}}$ when using standard saline solutions). The principles underlying this method derive from the equation describing the current $I_{\mathrm{C}}$ flowing onto (and off of) the membrane, $I_{\mathrm{C}}=C_{\mathrm{m}}\left[\mathrm{d} V_{\mathrm{m}} / \mathrm{dt}\right]$ and are discussed in Armstrong and Gilly (1992). $I_{\mathrm{C}}$ was measured as the difference between the current at the end of the voltage ramp and the steady-state current achieved after completion of the ramp. The voltage at the end of the ramp protocol was maintained for $47 \mathrm{msec}$ to ensure that the decay of the maximum current had reached steady-state. Because $\mathrm{dV} / \mathrm{dt}$ is $10 \mathrm{~V} / \mathrm{sec}$ in the experiments here, $C_{\mathrm{m}}=0.1\left[I_{\mathrm{C}}\right]$. The $C_{\mathrm{m}}$ calculated using this method was similar to the $C_{\mathrm{m}}$ determined using the classical method of calculating the time constant of the current response elicited by a $10 \mathrm{mV}$ voltage step (data not shown).

Cell capacitance measurements provided an assessment of cell coupling (de Roos et al., 1996). The mean single cell $C_{\mathrm{m}}$ depended on the cell morphology. Single neuroblast-like cells had $C_{\mathrm{m}}$ values of $\sim 2 \mathrm{pF}$ similar to the lowest values obtained for cells in clusters (23 of $107 \mathrm{had}$ $C_{\mathrm{m}}$ values of $<3 \mathrm{pF}$ ). To assess the effects of cell coupling, 1-Octanol (OCT, $1 \mathrm{~mm}$ ) was used; however, it was found to decrease the $C_{\mathrm{m}}$ from 10.3 to $4.1 \mathrm{pF}$ in only one of 10 examined clusters. The $C_{\mathrm{m}}$ of these OCT-insensitive cells was 1.7, 3.3, 4.5, 4.9, 4.9, 5.7, 7.8, 8.7, and $14.4 \mathrm{pF}$. Based on the $C_{\mathrm{m}}$ values for a single cell, only one cell was not electrically coupled $(1.7 \mathrm{pF})$, whereas all of the other observed cells in clusters were coupled; this offered the best biological approximation of the normal state of neuroblasts in the VZ, based on previous analyses demonstrating that VZ cells are coupled in groups of 15-90 cells (LoTurco and Kriegstein, 1991; Bittman et al., 1997).

Current densities were calculated as the peak $I_{\text {in }}$ or maximal $I_{\text {out }}$ at a voltage step to $+32 \mathrm{mV}$ normalized to the cell capacitance. Voltageactivated currents were obtained by voltage steps between -88 and +112 $\mathrm{mV}$ from a holding potential of $-98 \mathrm{mV}$. Membrane resistance $\left(R_{\mathrm{m}}\right)$ values were determined by voltage-ramp (the inverse of the slope of the ramp-induced current at negative potentials) or current-clamp protocols using small current injections and were similar $(n=9)$. Estimated $R_{\mathrm{s}}$ errors were no more than $1.5 \mathrm{mV}$, on average $<1 \mathrm{mV}$.

Apparent reversal potentials $\left(V_{\text {rev }}\right)$ of ligand-induced conductance changes were determined using a voltage-ramp protocol (Dubin and Dionne, 1994). Voltage ramps were applied every $6 \mathrm{sec}$, and the resulting whole-cell ramp-induced currents were recorded. Usually the voltage was ramped from positive to negative values to avoid the nonlinearity introduced by the voltage-activated $I_{\text {in }}$ when present at high density; however, in cells with large outward currents, the protocol was also reversed to enable the detection of small LPA-induced currents. The current required to clamp the cells at $-68 \mathrm{mV}$ was continuously monitored. Ligand-induced conductances were determined from whole-cell currents elicited by a voltage-ramp protocol in the presence and absence of ligand. Control ramp currents were subtracted from those obtained in the presence of ligand to produce difference currents, revealing the component of the whole-cell current-voltage relationship contributed by ligandinduced currents. The voltage at which there was no net ligand-induced current was determined $\left(V_{\text {rev }}\right)$. A criterion used to avoid spurious $V_{\text {rev }}$ determinations was that at least three individual ramps during the response revealed a similar $V_{\text {rev }}$. This was possible because the responses were quite long-lasting. The figures show the difference ramp comparing the initial ramp after onset of the response and the average of control ramps. The concentrations of the major ions in the intracellular and extracellular salines were set such that each ion had a unique equilibrium potential. The equilibrium potentials for $\mathrm{Na}^{+}, \mathrm{K}^{+}$, and $\mathrm{Cl}^{-}$under the normal recording conditions were $+85,-85$, and $-40 \mathrm{mV}$, respectively. The recorded current trace was filtered off-line (at $1 \mathrm{~Hz}$ ), and in some 


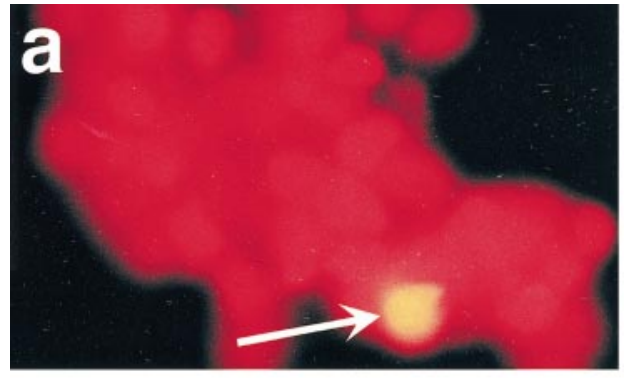

C

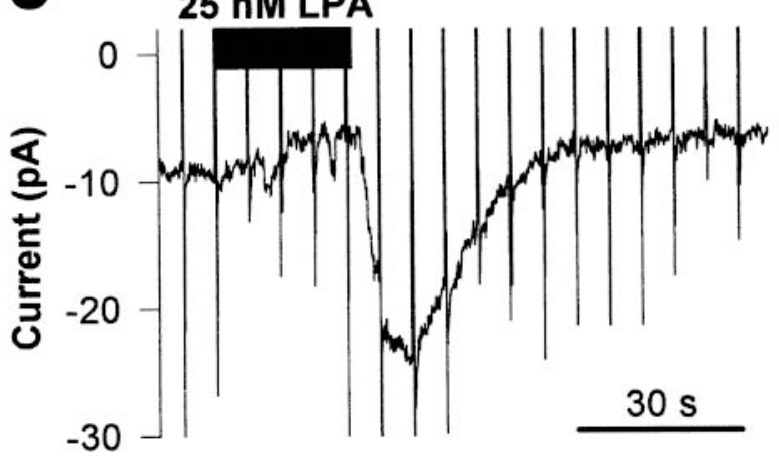

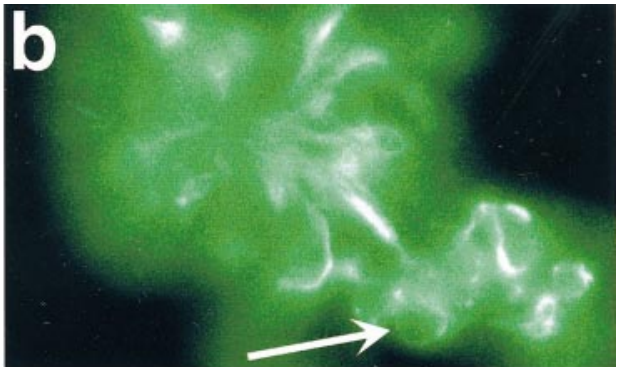

d

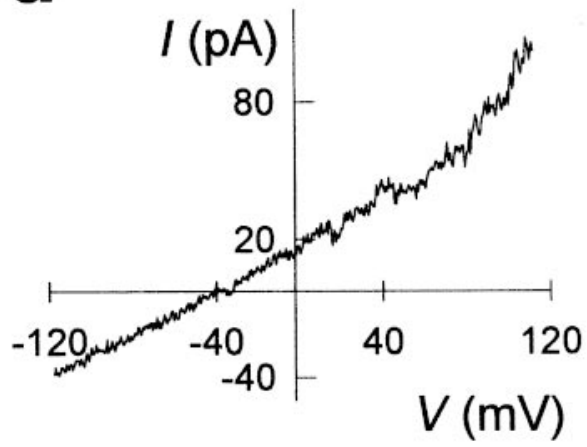

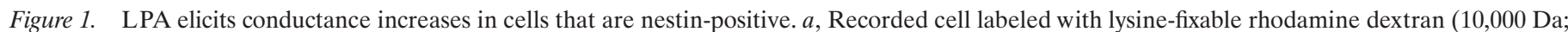

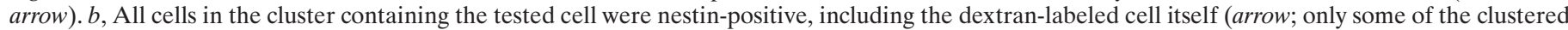

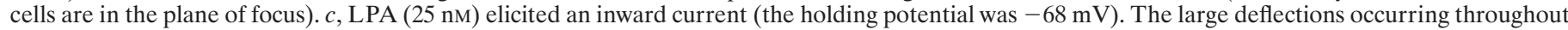

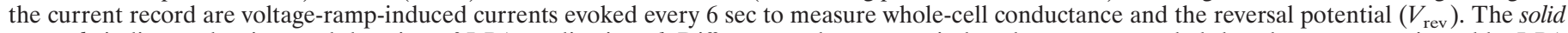

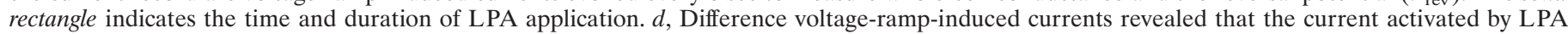
had a reversal potential $\left(V_{\mathrm{rev}}=-39 \mathrm{mV}\right)$ near the $E_{\mathrm{Cl}}(-40 \mathrm{mV})$, consistent with an LPA-induced increase in $\mathrm{Cl}^{-}$conductance.

Table 1. Resting membrane properties of presumptive neuroblasts from E11 (acute) and E12 cortices [acute and after 12-20 hr in vitro without serum $($ E12-13)]

\begin{tabular}{lclc} 
Age & $\begin{array}{l}\text { Resting } \\
\text { potential } \\
(\mathrm{mV})[n]^{a}\end{array}$ & $\begin{array}{l}C_{\mathrm{m}}{ }^{b}(\mathrm{pF})[n] \\
\text { range }\}\end{array}$ & $\begin{array}{l}R_{\mathrm{m}} \\
(\mathrm{G} \Omega)^{c}[n]\end{array}$ \\
\hline Acute E11 & $-48 \pm 5$ & $6.6 \pm 1.1[n=53]$ & $3.1 \pm 0.3$ \\
& {$[n=12]$} & $\{1.0-30.4\}$ & {$[n=51]$} \\
Acute E12 & $-42 \pm 6$ & $5.0 \pm 0.6[n=61]$ & $3.5 \pm 0.6$ \\
& {$[n=5]$} & $\{1.8-26.7\}$ & {$[n=31]$} \\
E12-13 & $-51 \pm 3$ & $5.8 \pm 0.4[n=107]$ & $3.2 \pm 0.4$ \\
& {$[n=10]$} & $\{1.5-32.2\}$ & {$[n=69]$}
\end{tabular}

The RP, $C_{\mathrm{m}}$, and $R_{\mathrm{m}}$ are reported from a variable group of clustered cells. ${ }^{a}$ The number of individual cells tested.

${ }^{b}$ Cells in clusters from all ages tested were often electrically coupled as indicated by their membrane capacitance $\left(C_{\mathrm{m}}\right)$.

${ }^{c}$ Shown is the whole-cell membrane resistance $\left(R_{\mathrm{m}}\right)$ for all tested cells. When cells were separated into groups with $C_{\mathrm{m}}$ either $<4$ or $>5 \mathrm{pF}$, the $R_{\mathrm{m}}$ of tentatively coupled cells $\left(C_{\mathrm{m}}>5 \mathrm{pF}\right)$ from acutely dissociated cultures was significantly larger than that of uncoupled cells $\left(C_{\mathrm{m}}<4 \mathrm{pF}\right)[\mathrm{E} 11,4.0 \pm 0.5 \mathrm{G} \Omega(n=25)$ vs $1.3 \pm 0.2$ $\mathrm{G} \Omega(n=12 ; p<0.00001) ; \mathrm{E} 12,4.7 \pm 1.0 \mathrm{G} \Omega(n=17)$ vs $2.2 \pm 0.6 \mathrm{G} \Omega(n=10 ; p<$ $0.05)]$.

traces only part of the positive voltage-ramp deflection is shown (see Figs. $4 a, c, e, 5 a, 6 a-c)$.

The LPA-induced conductance was calculated from voltage-ramp data. The conductance was calculated from the linear portion of rampinduced current-voltage curve at negative potentials $(I=\mathrm{G} * \mathrm{~V}$, where $\mathrm{G}$ is the slope). The control conductance (usually the average of two or three traces before the LPA-induced response) was subtracted from the largest conductance measured in the presence of LPA. The LPAinduced conductance determined by this method was underestimated because the peak response often was not captured during the ramp protocol.

Most values are presented as the arithmetic mean \pm SEM. Because $I_{\mathrm{Na}}$ values had a skewed distribution, geometric means were determined, and the reported values are the arithmetic means with the upper and lower error limits in parentheses (Hancock et al., 1988). For the latter calculation, a value of $0 \mathrm{pA} / \mathrm{pF}$ was given to cells with no detectable inward $I_{\mathrm{Na}}$ and averaged with the natural log of the other values.

Ligand reagents. LPA was thoroughly dissolved in Milli-Q water and used fresh or stored frozen as a $5 \mathrm{~mm}$ stock solution and used within $5 \mathrm{~d}$. It was diluted to the indicated concentrations in extracellular saline and applied at concentrations ranging from $10 \mathrm{nM}$ to $1 \mu \mathrm{M}$ from nearby puffer pipettes. As a control for possible nonspecific lipid effects, a structurally related compound, lysophosphatidyl glycerol (LPG), was applied at concentrations between $10 \mathrm{~nm}$ and $10 \mu \mathrm{M}$. Stocks of GABA (100 mm) and L-glutamate $(300 \mathrm{~mm})$ were stored frozen and thawed only once and diluted in extracellular saline just before use. Ligand was applied (3-10 psi) together with $0.05 \%$ fast green dye to mark the plume using a Picospritzer (General Valve, Fairfield, NJ) for durations indicated in the figures (typically 15-25 sec).

BrdU and nestin immunofluorescence. To determine the proliferative capacity of primary cells, cultures were pulsed at the time of plating with bromodeoxyuridine (BrdU), and BrdU immunofluorescence was detected 24 hr later (cell proliferation kit; Boehringer Mannheim, Indianapolis, IN). For nestin immunofluorescence, coverslips containing cells that had been filled with lysine-fixable rhodamine-dextran during recording (see above) were fixed for $15 \mathrm{~min}$ with $4 \%$ paraformaldehyde in PBS. After PBS rinses, coverslips were incubated with blocking solution $(2.5 \%$ BSA, $0.3 \%$ Triton $\mathrm{X}-100$ in PBS) for $1 \mathrm{hr}$, followed by monoclonal anti-nestin antibody (PharMingen, La Jolla, CA) at 1:500 in blocking solution overnight. Coverslips were rinsed with PBS and incubated with FITC-conjugated anti-mouse IgG secondary antibody (Pierce, Rockford, IL) at 1:100 for $1 \mathrm{hr}$. After PBS rinses, all coverslips were counterstained with the fluorescent nuclear stain 4'6-diamidino-2-phenylindole (DAPI; Sigma, St. Louis, MO), air-dried, and mounted on glass microscope slides in GelMount (Biomeda, Foster City, CA). Coverslips were exam- 
Figure 2. Recorded cells from primary cultures of dissociated cortex have electrical properties of neuroblasts. Small cell clusters ( $\sim 10-50$ cells $)$ from E12 telencephala were examined between 2 and $20 \mathrm{hr}$ after plating and examined as small aggregates. $a$, Fast transient inward currents (negative values in the figure) could be observed in LPAresponsive cells. Whole-cell currents were elicited by voltage steps ( $40 \mathrm{msec}$ duration) between -58 and $+42 \mathrm{mV}$ in increments of 20 $\mathrm{mV}$ from a holding potential of $-98 \mathrm{mV}$. The peak inward current was $-15.6 \mathrm{pA} / \mathrm{pF}$. $b$, The current-voltage relationship of the voltageactivated currents elicited for the neuroblast shown in Figure $2 a$. Peak inward $\left(I_{\text {in }} ;\right.$ circles $)$ and steady-state outward $\left(I_{\text {out }} ;\right.$ squares $)$ currents (in picoamperes) are plotted against the step voltage. $c$, The fast transient inward currents are TTX-sensitive. Whole-cell currents were elicited by voltage steps to $-68,-28,2$, and $32 \mathrm{mV}$ from a holding potential of -98 $\mathrm{mV}$. The recording electrode contained $\mathrm{Cs}^{+}$ IS; bath contained Tyrode's. Left, Fast transient $I_{\text {in }}(-12.3 \mathrm{pF} / \mathrm{pA})$ before bath puffer application of TTX $(2 \mu \mathrm{M})$; center, during exposure to TTX; right, partial recovery $3 \mathrm{~min}$ after washout of TTX. a

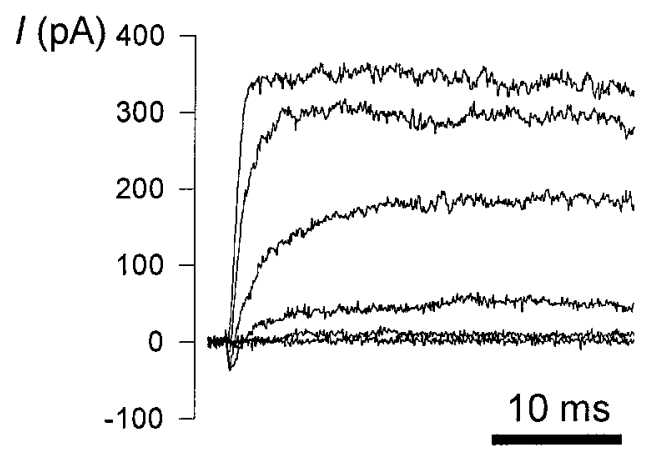

C

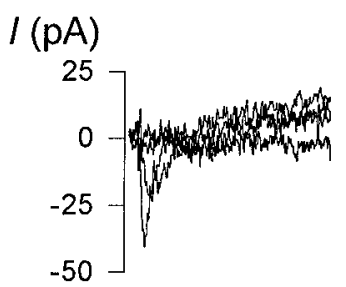

$I(\mathrm{pA})$ b
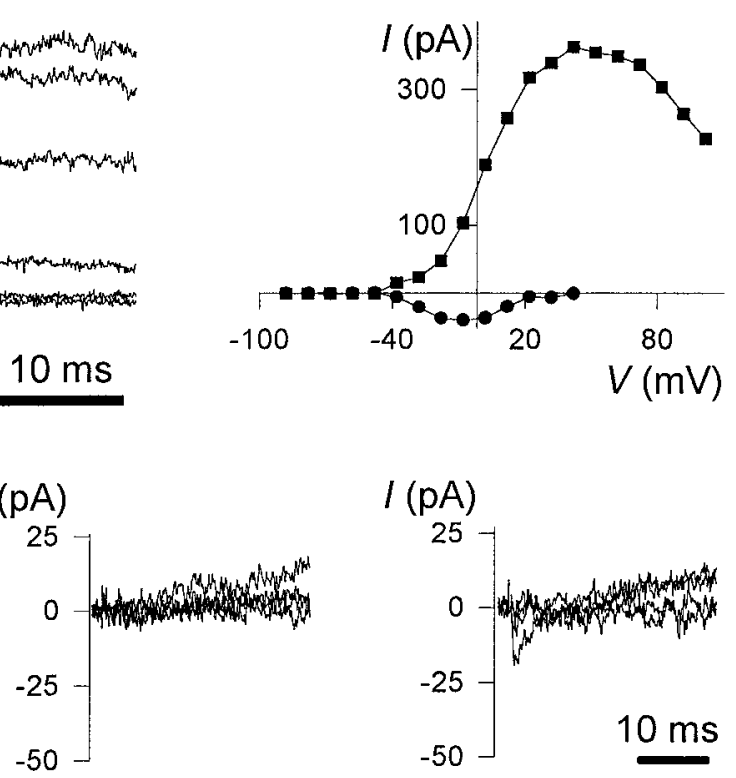

ined and photographed using a Zeiss Axioskop fluorescence microscope with rhodamine, fluorescein, or DAPI filters.

\section{RESULTS}

Cells comprising small clusters of 10-50 cells were examined for features consistent with a neuroblast identity in primary cultures derived from E11 and E12 dissociated murine cortices. Single cells that were part of clusters were studied because they offered the closest biological approximation of the actual electrical state of neuroblasts in the VZ, based on extensive previous studies demonstrating that $\mathrm{VZ}$ cells are normally coupled in groups of 15-90 cells (LoT urco and Kriegstein, 1991; Bittman et al., 1997). In addition, the resting membrane potentials of the examined cells in clusters were very similar to those reported previously, as were responses to GABA and L-glutamate (see below), demonstrating that this culture system supported physiological parameters of previous reports. Moreover, single cells from a cortical neuroblast cell line that were not electrically coupled showed similar results to cells in clusters. Changes in membrane conductance elicited after rapid, local exposure of these primary cells to LPA or both GABA and L-glutamate were assayed between 1 and $20 \mathrm{hr}$ in vitro under serum-free conditions using the whole-cell variation of the patch-clamp technique. In addition to being tested for electrophysiological properties, recorded cells were labeled using fluorescent dextran, fixed, then double-labeled for nestin immunofluorescence. In some cases, BrdU pulses were also used to determine the percentage of cells undergoing DNA synthesis. Two distinct LPA-induced conductance changes were observed in putative neuroblasts: a $\mathrm{Cl}^{-}$conductance increase and a NSC conductance increase. LPA responsiveness always preceded that of GABA or L-glutamate during development.

\section{LPA-responsive cells can incorporate BrdU and are nestin-immunoreactive}

To determine the percentage of cells still undergoing DNA synthesis and expressing the neural precursor protein nestin (Cataneo and McKay, 1990), primary cultures at E12 were exposed to BrdU and processed for immunofluorescence. When these cul- tures were treated with BrdU for $24 \mathrm{hr}$ to label cells undergoing DNA synthesis, $87 \%$ of cells showed BrdU immunoreactivity (data not shown). This value is consistent with the proliferative capacity of VZ cells that have been reported to be electrically coupled (LoT urco and Kriegstein, 1991; Bittman et al., 1997), as were the cells assayed here. More than $80 \%$ of the cells were also nestin-immunoreactive. To ascertain the relationship between electrophysiological properties and nestin immunoreactivity, these cells, which could be easily identified by their stereotypic clustering, were first assayed electrophysiologically, filled with lysine-fixable rhodamine dextran (Fig. 1a), then immunostained for nestin (Fig. 1b). This particular cell responded to LPA (25 nM) with an increase in $\mathrm{Cl}^{-}$conductance $\left(G_{\mathrm{Cl}}\right)$ (Fig. 1c,d).

\section{Membrane electrical properties}

The majority of nestin-immunoreactive cell clusters produced from dissociated cortices at E11 or E12 and tested acutely, or E12 cells cultured 12-20 hr under serum-free conditions (noted as E12-E13), exhibited membrane properties that were consistent with previously reported values for rodent embryonic cortical neuroblasts (LoTurco et al., 1991) (Table 1). Many cells expressed depolarization-activated fast transient inward currents (Fig. 2a,b) that remained stable over the recording period (at least $10 \mathrm{~min}$ ). The apparent threshold voltage for $I_{\text {in }}$ activation was between -40 and $-50 \mathrm{mV}$, and the peak current was elicited near $-10 \mathrm{mV}$ (Fig. $2 b$ ). Half the channels were inactivated when the membrane was held at a 500 msec prepulse potential of $-62 \pm 1$ $\mathrm{mV}(n=8)$. These inward currents were completely blocked by 2 $\mu \mathrm{M}$ tetrodotoxin under conditions in which voltage-activated $\mathrm{K}^{+}$ currents were blocked by intracellular $\mathrm{Cs}^{+}$(to avoid outward current contamination of $I_{\text {in }}$ ), indicating $I_{\text {in }}$ was mediated by $\mathrm{Na}^{+}$ and not $\mathrm{Ca}^{2+}$ (Fig. $2 c$ ). Peak $I_{\mathrm{Na}}$ current densities were often $<10$ $\mathrm{pA} / \mathrm{pF}$ (Fig. $3 a-c ; 62 \%$ at E11; 42\% at E12; 40\% at E12-13). Except for rare cells with very large $I_{\mathrm{Na}}(>75 \mathrm{pA} / \mathrm{pF})$ that could be maturing subplate neurons present at this embryonic stage (Chun et al., 1987), overshooting action potentials could not be elicited. 
$\mathbf{A}$

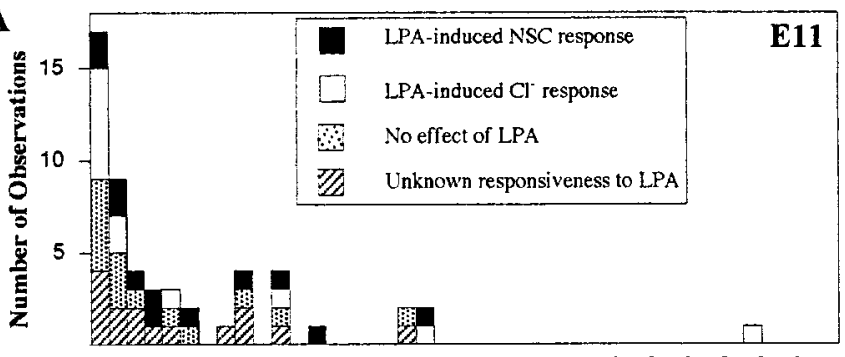

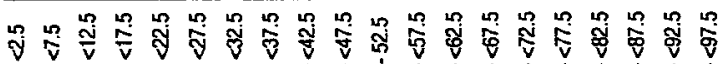

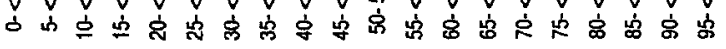
$\mathrm{Na}^{+}$Current Density $(\mathrm{pA} / \mathrm{pF})$
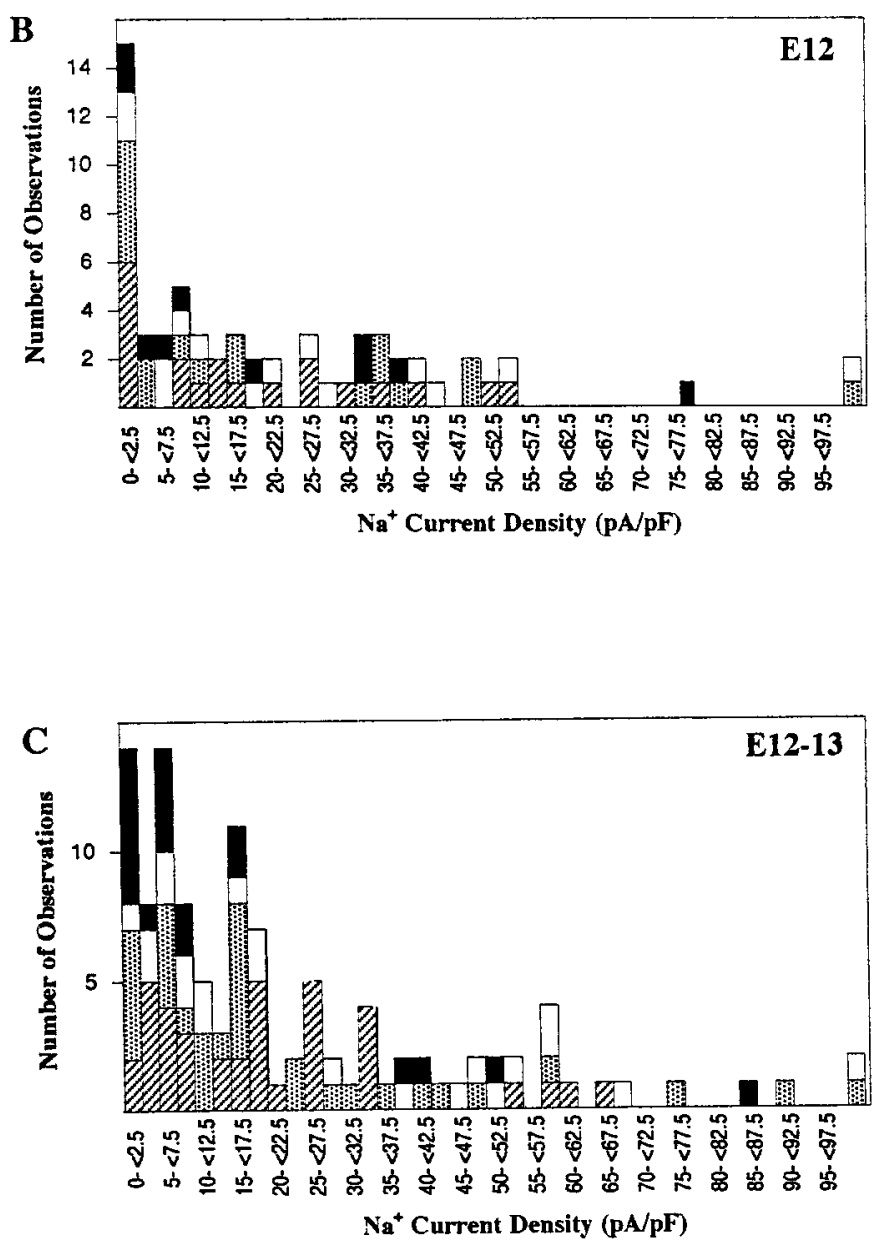

Figure 3. Histograms of peak $\mathrm{Na}^{+}$current density (in picoamperes per picofarad) of cells tested. Solid bars, Cells that responded with an NSC conductance; open bars, cells that responded with an increased $\mathrm{Cl}^{-}$ conductance; stippled bars, cells that revealed no detectable effect of LPA ( $\geq 10 \mathrm{nM}$ ); hatched bars, cells were either not tested for LPA sensitivity or possible responses were obscured by spontaneous activity (these were not included in the response data). A significant proportion of cells exhibited no voltage-activated fast transient inward currents from holding potentials of $-98 \mathrm{mV}$. In E11, E12, and E12-E13 cultures, $22 \%(n=53), 22 \%(n=$ $62)$, and $11 \%(n=110)$ of cells, respectively, revealed no detectable inward currents, despite other cell properties indicating that they were healthy (e.g., RP, $\left.R_{\mathrm{m}}\right) . A$, E11 acute; $B, \mathrm{E} 12$ acute; $C, \mathrm{E} 12-\mathrm{E} 13$.
Outward currents $\left(I_{\text {out }}\right)$ were also elicited by voltage depolarizations (Fig. $2 b$ ). The maximum $I_{\text {out }}$ elicited by a step to $+32 \mathrm{mV}$ was $+46.2 \pm 4.9 \mathrm{pA} / \mathrm{pF}(n=50),+57.0 \pm 8.3 \mathrm{pA} / \mathrm{pF}(n=30)$, and $+61.6 \pm 5.9 \mathrm{pA} / \mathrm{pF}(n=77)$ at E11, E12, and E12-E13, respectively. On E11 and E12, most cells revealed a sustained $I_{\text {out }}$ over a 40 msec voltage step [84\% $(n=44)$ and $74 \%(n=31)$ of the cells, respectively]. However, at E12-E13 most cells (57\%; $n=37$ ) revealed an inactivating component. Many cells revealed an N-shaped current-voltage relationship of $I_{\text {out }}$ at very positive voltages, usually indicative of the presence of $\mathrm{Ca}^{2+}$-activated currents. Although only a quarter of the E11 cells $(26 \% ; n=43)$ revealed this characteristic, $50 \%(n=28)$ and $61 \%(n=31)$ of E12 and E12-E13 cells did so. There were no significant differences in cell electrical properties $\left(C_{\mathrm{m}}, R_{\mathrm{m}}, I_{\mathrm{Na}}, I_{\text {out }}\right)$ between the populations of cells responsive to LPA (see below) and those with no detectable LPA sensitivity (data not shown).

\section{LPA activates two distinct electrical responses in different populations of cells}

LPA increased the membrane conductance without altering voltage-activated currents in 58\% $(n=131)$ of cells from all ages tested. Two cell populations with distinct responses were identified, based on the reversal potential $\left(V_{\text {rev }}\right)$ using a voltage-ramp protocol and ion substitution. In physiological solutions, $30 \%$ of cells responded to LPA with an increase in conductance that reversed near the $\mathrm{Cl}^{-}$equilibrium potential $\left(E_{\mathrm{Cl}} ;-40 \mathrm{mV}\right)$ (Table 2, Figs. $1 c, d, 4 a, b)$. The remaining group of sensitive cells (28\%) responded to LPA with a conductance increase having a $V_{\text {rev }}$ near $0 \mathrm{mV}$, consistent with its mediation by NSCs (Table 2, Fig. $5 a, b)$. Both types of responses displayed homologous desensitization to LPA at tested concentrations within $10 \mathrm{~min}$ (Fig. $5 a$ ). LPG (or other non-LPA ligands; data not shown) exposure never induced membrane conductances like those observed with LPA (Fig. 4a).

\section{LPA-induced $\mathrm{Cl}^{-}$conductances}

LPA-activated $\mathrm{Cl}^{-}$conductances were observed at all ages tested (Table 2). The percentage of cells responding with an increase in $G_{\mathrm{Cl}}$ was similar in E11, E12, and E12-E13 cultures. Latencies were $\sim 30 \mathrm{sec}$ (Table 2 ). The average peak $I_{\mathrm{Na}}$ density was low at E11 and increased at later times (Table 2), but it can be clearly seen in Figure 3 that many $\mathrm{Cl}^{-}$responses were observed in cells with little or no $I_{\mathrm{Na}}$ at each age tested (Fig. 3, open bars). The $I_{\text {out }}$ density was no different from that observed in the population of cells with increased NSC conductances (Table 2).

The ionic dependence of LPA responses was investigated in $\mathrm{Cl}^{-}$ion substitution experiments. Approximately $36 \%$ of examined cells bathed in low $\mathrm{Cl}^{-}$saline revealed an increased conductance with a $V_{\text {rev }}(+39 \pm 5 \mathrm{mV} ; n=8)$ shifted toward the predicted $E_{\mathrm{C} 1}(+70 \mathrm{mV})$ (Fig. $\left.4 c, d\right)$ and significantly more positive than that expected for a NSC conductance ( $p<0.01$; Fig. 5). In contrast, $\sim 14 \%$ of cells responded with a $V_{\text {rev }}$ near $0 \mathrm{mV}(2 \pm$ $1 \mathrm{mV} ; n=3$ ) in low $\mathrm{Cl}^{-}$saline. These results demonstrate the existence of two distinct, LPA-dependent responses, one dependent on $\mathrm{Cl}^{-}$, and the other consistent with mediation by NSC channels.

$G_{\mathrm{Cl}}$ responses could also be elicited in a cell line derived from cortical neuroblasts of the VZ (cell line TSM; Chun and Jaenisch, 1996) stably transfected to overexpress the cloned LPA receptor gene $l p_{\mathrm{A} 1} / v z g-1$ (Hecht et al., 1996) (Fig. 4e,f). In standard salines, $V_{\text {rev }}$ was $-31 \pm 2 \mathrm{mV}(n=4), G_{\mathrm{LPA}}$ was $0.56 \pm 0.27 \mathrm{nS}$, and the response latency was $49 \pm 25 \mathrm{sec}$. These cells exhibited electrical 


\begin{tabular}{|c|c|c|c|c|c|c|c|c|c|}
\hline $\begin{array}{l}\text { Response }^{a} \text { to LPA } \\
(10 \mathrm{nM}-1 \mu \mathrm{M})\end{array}$ & Age & $\begin{array}{l}\text { Percent } \\
\text { observed } \\
(n)\end{array}$ & $V_{\text {rev }}^{b}(\mathrm{mV})$ & ${ }^{\mathrm{G}} \mathrm{LPA}^{c}(\mathrm{pS})$ & $\begin{array}{l}\text { Latency } \\
(\mathrm{sec})\end{array}$ & $C_{\mathrm{m}}(\mathrm{pF})$ & $\begin{array}{l}R_{\mathrm{m}}(\mathrm{G} \Omega) \\
\text { (only Tyr/ } \\
\text { ZIS) }\end{array}$ & $\begin{array}{l}\text { Peak } I_{\mathrm{Na}} \text { density } \\
(\mathrm{pA} / \mathrm{pF})^{\mathrm{d}}\end{array}$ & $\begin{array}{l}I_{\text {out }} \text { elicited } \\
\text { at }+32 \mathrm{mV} \\
(\mathrm{pA} / \mathrm{pF})\end{array}$ \\
\hline \multirow[t]{3}{*}{ Increased $\mathrm{G}_{\mathrm{Cl}}$} & Acute E11 & $\begin{array}{l}32 \% \\
(n=38)\end{array}$ & $\begin{array}{l}-36 \pm 2 \\
(n=12)\end{array}$ & $\begin{array}{l}0.46 \pm 0.12 \\
(n=12)\end{array}$ & $\begin{array}{l}28 \pm 6 \\
(n=12)\end{array}$ & $\begin{array}{l}8.4 \pm 2.1 \\
(n=12)\end{array}$ & $\begin{array}{l}3.0 \pm 0.8 \\
(n=12)\end{array}$ & $\begin{array}{l}-3.8(-2.3,-6.3) \\
(n=12)\end{array}$ & $\begin{array}{l}48.2 \pm 9.4 \\
(n=12)\end{array}$ \\
\hline & Acute E12 & $\begin{array}{l}33 \% \\
(n=42)\end{array}$ & $\begin{array}{l}-37 \pm 2 \\
(n=11)\end{array}$ & $\begin{array}{l}0.22 \pm 0.02 \\
(n=14)\end{array}$ & $\begin{array}{l}31 \pm 5 \\
(n=14)\end{array}$ & $\begin{array}{l}4.5 \pm 0.7 \\
(n=14)\end{array}$ & $\begin{array}{l}3.1 \pm 1.1 \\
(n=8)\end{array}$ & $\begin{array}{l}-11.5(-8.2,-16.1) \\
(n=14)\end{array}$ & $\begin{array}{l}52.3 \pm 13.6 \\
(n=8)\end{array}$ \\
\hline & E12-13 & $\begin{array}{l}25 \% \\
(n=51)\end{array}$ & $\begin{array}{l}-34 \pm 2 \\
(n=15)\end{array}$ & $\begin{array}{l}0.79 \pm 0.18 \\
(n=15)\end{array}$ & $\begin{array}{l}39 \pm 7 \\
(n=22)\end{array}$ & $\begin{array}{l}5.7 \pm 0.7 \\
(n=21)\end{array}$ & $\begin{array}{l}3.9 \pm 0.6 \\
(n=13)\end{array}$ & $\begin{array}{l}-16.8(-13.1,-21.6) \\
(n=21)\end{array}$ & $\begin{array}{l}66.4 \pm 8.6 \\
(n=14)\end{array}$ \\
\hline \multirow[t]{3}{*}{ Increased $\mathrm{G}_{\mathrm{NSC}}$} & Acute E11 & $\begin{array}{l}32 \% \\
(n=38)\end{array}$ & $\begin{array}{l}-6 \pm 2 \\
(n=11)\end{array}$ & $\begin{array}{l}0.87 \pm 0.34 \\
(n=11)\end{array}$ & $\begin{array}{l}42 \pm 6 \\
(n=11)\end{array}$ & $\begin{array}{l}6.0 \pm 2.5 \\
(n=11)\end{array}$ & $\begin{array}{l}4.1 \pm 0.6 \\
(n=11)\end{array}$ & $\begin{array}{l}-7.9(-5.3,-11.7) \\
(n=11)\end{array}$ & $\begin{array}{l}35.9 \pm 7.2 \\
(n=10)\end{array}$ \\
\hline & Acute E12 & $\begin{array}{l}24 \% \\
(n=42)\end{array}$ & $\begin{array}{l}-3 \pm 3 \\
(n=6)\end{array}$ & $\begin{array}{l}0.95 \pm 0.58 \\
(n=10)\end{array}$ & $\begin{array}{l}44 \pm 11 \\
(n=10)\end{array}$ & $\begin{array}{l}5.8 \pm 1.2 \\
(n=10)\end{array}$ & $\begin{array}{l}2.7 \pm 0.8 \\
(n=7)\end{array}$ & $\begin{array}{l}-10.5(-6.5,-17.0) \\
(n=9)\end{array}$ & $\begin{array}{l}60.5 \pm 18.4 \\
(n=4)\end{array}$ \\
\hline & E12-13 & $\begin{array}{l}29 \% \\
(n=51)\end{array}$ & $\begin{array}{l}-9 \pm 2 \\
(n=13)\end{array}$ & $\begin{array}{l}0.82 \pm 0.16 \\
(n=13)\end{array}$ & $\begin{array}{l}48 \pm 9 \\
(n=13)\end{array}$ & $\begin{array}{l}5.2 \pm 1.0 \\
(n=18)\end{array}$ & $\begin{array}{l}2.8 \pm 0.8 \\
(n=11)\end{array}$ & $\begin{array}{l}-4.6(-3.3,-6.2) \\
(n=17)\end{array}$ & $\begin{array}{l}46.6 \pm 9.6 \\
(n=12)\end{array}$ \\
\hline
\end{tabular}

${ }^{a}$ The proportion of responsive cells is likely an underestimate since spontaneous current fluctuations may have obscured real but small effects.

${ }^{b}$ The difference in $V_{\text {rev }}$ of the LPA response elicited from the two groups $\left(\mathrm{Cl}^{-}\right.$vs NSC) was statistically significant $\left(p<10^{-8}\right.$, Student's $t$ test).

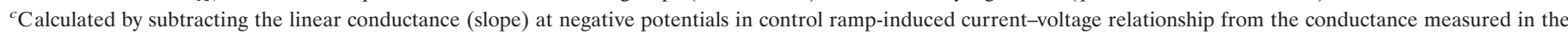

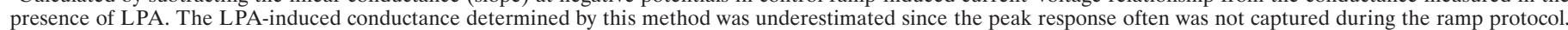

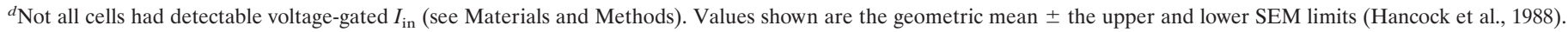

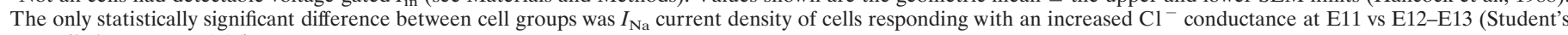
two-tailed $t$ test; $p<0.05$ ).

properties similar to those expected for neuroblasts: $I_{\mathrm{Na}}$ was -2.2 $\mathrm{pA} / \mathrm{pF}\left(-1.7,-3.0\right.$ upper and lower error limits), $R_{\mathrm{m}}$ was $3.1 \pm$ $0.7 \mathrm{G} \Omega$, and no action potentials could be elicited by depolarizing current injection. Unlike primary cells in clusters, TSM cells could be assayed as single cells. Nevertheless, these single cells showed similar electrical properties and $G_{\mathrm{C} 1}$ values and latencies after LPA exposure despite their lack of electrical coupling.

\section{LPA-induced NSC conductances}

LPA-activated NSC conductances were observed at all ages tested (Table 2). The percentage of cells responding with an increase in $G_{\mathrm{NSC}}$ and the magnitude of the response $\left(G_{\mathrm{LPA}}\right)$ was similar in E11, E12, and E12-E13 cultures (Fig. 5a,b, Table 2). Response latencies were $\sim 45 \mathrm{sec}$. Figure 3 shows that many NSC responses were observed in cells with little or no $I_{\mathrm{Na}}$ at each age tested (solid bars).

The ionic dependence of this putative NSC response was investigated by ion substitution experiments in which the intracellular milieu was perfused with impermeant cations (ZIS intracellular solution). With Tyrode's in the bath and ZIS in the pipette, an NSC conductance is predicted to have a $V_{\mathrm{rev}} \gg 0 \mathrm{mV}$ and $E_{\mathrm{C} 1}$ that is negative $(-69 \mathrm{mV})$. If this class of LPA-induced response was caused by nonspecific membrane breakdown, then the $V_{\text {rev }}$ should remain near $0 \mathrm{mV}$. With ZIS in the pipette, however, eight cells responded to LPA $(25 \mathrm{nM})$ with an increase in conductance that had a $V_{\text {rev }}$ significantly more positive than $0 \mathrm{mV}$ (Fig. $5 c, d$; $+32 \pm 5 \mathrm{mV} ; p<0.0005$ compared with the $V_{\text {rev }}$ obtained under standard conditions). Other cells responded with a $V_{\text {rev }}$ near -69 $\mathrm{mV}$ as expected for an increased $G_{\mathrm{C} 1}$ (data not shown). $G_{\mathrm{NSC}}$ responses could be elicited in a subpopulation of cells from the TSM stable cell line (data not shown).

\section{LPA responsiveness precedes that of GABA or L-glutamate}

Previous work indicated that the onset of GABA and L-glutamate responses in rat cortex commenced at a developmental period corresponding to murine E11-E12 (LoTurco et al., 1995). To determine whether LPA effects can be observed earlier in devel- opment than GABA or L-glutamate responsiveness, E11-E12 cells were cultured and exposed to either LPA (10-25 nM) or a combined stimulus consisting of GABA $\left(\begin{array}{lll}100 \mu \mathrm{M}\end{array}\right)$ and L-glutamate $(300 \mu \mathrm{M})$. GABA and L-glutamate were applied simultaneously because the reversal potential of responses to these two ligands are distinct [near $-40 \mathrm{mV}\left(E_{\mathrm{C} 1}\right)$ and $\sim 0 \mathrm{mV}$, respectively], allowing unambiguous ligand identification based on reversal potential while using a single delivery pipette. Acutely dissociated cells from E11, examined within $3 \mathrm{hr}$ of plating, possessed only LPA sensitivity ( $n=7$; Fig. $6 a$,d). By late E11, both LPA and neurotransmitter responses could be seen in similar proportions (Fig. $6 d$; an example of an E12 cell is shown in Fig. $6 b)$. E12 and E12-E13 cells were most often sensitive to a single ligand (48\%), however a small population responded to both LPA and either GABA or L-glutamate (26\%; Fig. $6 b)$. It is unlikely that the lack of GABA/L-glutamate responsiveness in early E11 cells is caused by the dissociation procedure because responses were observed within $1 \mathrm{hr}$ after plating E12 embryonic cortices. At E12-E13, the $V_{\text {rev }}$ of responses elicited by GABA/Lglutamate application was usually near $E_{\mathrm{Cl}}\left(V_{\mathrm{rev}}\right.$ of $-38 \pm 2 \mathrm{mV}$; $n=8$ of 9 cells), suggesting that the neurotransmitter response was mediated by $\mathrm{GABA}_{\mathrm{A}}$ receptors. The GABA-induced conductance ranged from $0.6 \pm 0.1 \mathrm{nS},(n=10 ; p<0.01)$ in the earliest examined cultures, to $1.8 \pm 0.4 \mathrm{nS}(n=8)$ at later times (Fig. 6c). Rarely, responses to GABA/L-glutamate application elicited a fast increase in conductance that reversed at $-3 \mathrm{mV}$ $(n=1)$, consistent with mediation by ionotropic glutamate receptors.

\section{DISCUSSION}

An expectation extending from LPA receptor gene expression in the cortical VZ (Hecht et al., 1996) was the existence of receptormediated actions of LPA influencing the physiology of cortical neuroblasts. In this study, LPA was found to stimulate two distinct conductances in separate populations of nestinimmunoreactive, putative neuroblasts present in cell clusters. These effects commenced at the earliest stages of cortical devel- 
a

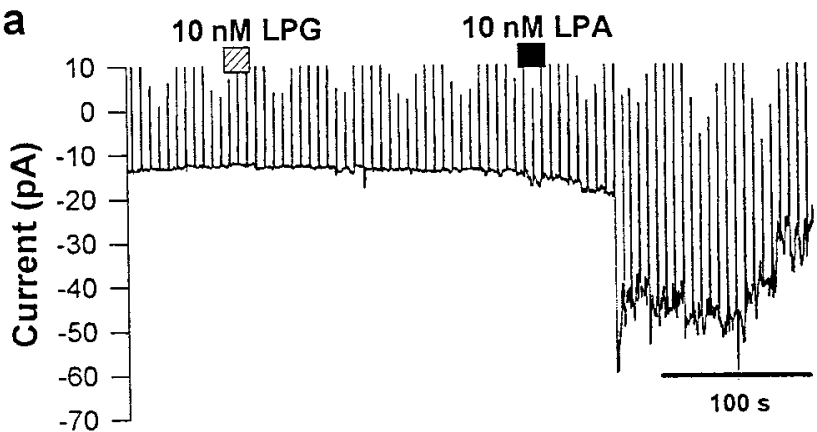

C
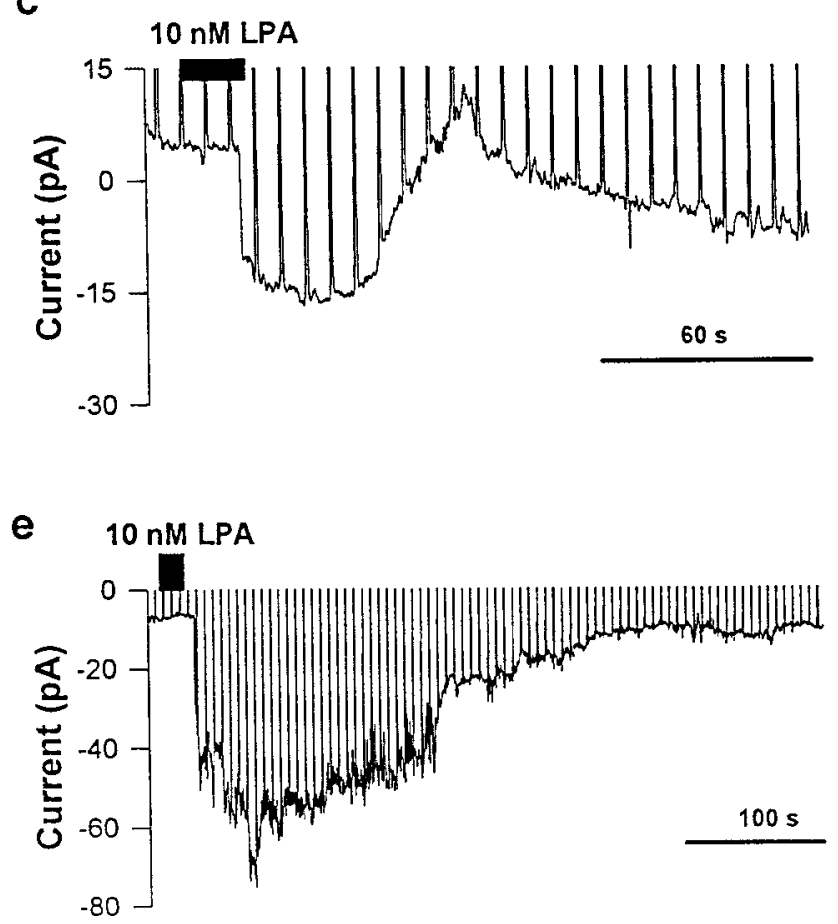

b

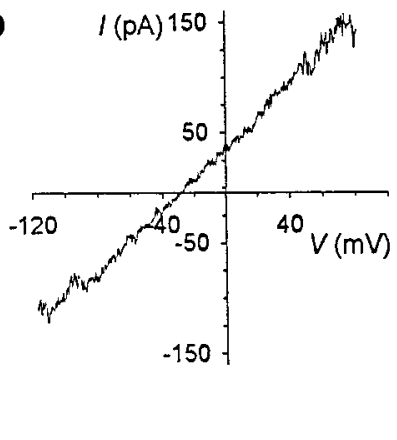

d
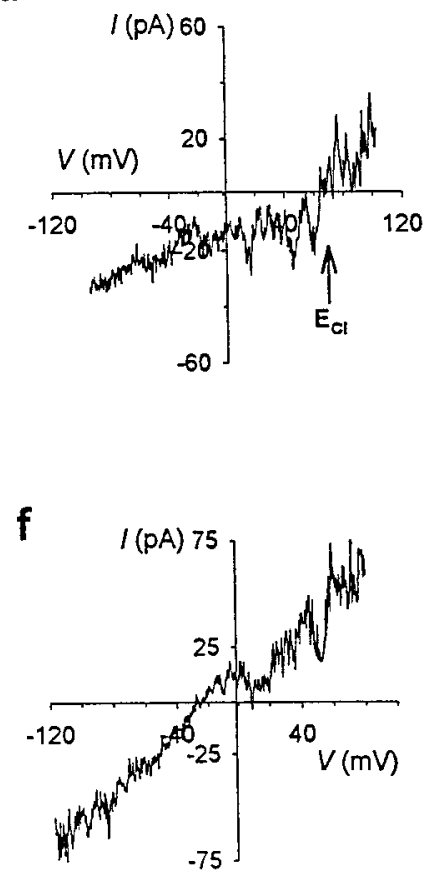

Figure 4. LPA exposure increases a membrane conductance mediated by chloride ions $\left(\mathrm{Cl}^{-}\right)$. Two different cells from primary cortical cultures (E12$\mathrm{E} 13 ; a-d)$ and a cell from an embryonic cortical cell line $(e, f)$ are shown. $a$, LPA exposure elicited an inward current and increase in conductance not produced by related compounds (shown for LPG). The large deflections occurring throughout the current record are voltage-rampinduced currents evoked every $6 \mathrm{sec}$ to measure whole-cell conductance and the reversal potential $\left(V_{\text {rev }}\right)$. Rectangles indicate time and duration of delivered ligand. Similar negative results with LPG were observed in seven of seven cells. $b$, $V_{\text {rev }}$ for the response shown in Figure $2 a$ is consistent with a $\mathrm{Cl}^{-}$-mediated conductance. The voltage was ramped from +82 to $-118 \mathrm{mV}$ at a rate of $1 \mathrm{mV} / \mathrm{msec}$. Plotted is the difference current calculated by subtracting the control voltageramp-induced currents from those obtained during LPA exposure. $V_{\text {rev }}$ was estimated at $-28 \mathrm{mV}$, similar to the $E_{\mathrm{Cl}}$ $(-40 \mathrm{mV}) . c$, Ion substitution demonstrates that some LPA-induced responses are mediated by $\mathrm{Cl}^{-}$. Cells were recorded in low- $\mathrm{Cl}^{-}$saline, where the predicted $E_{\mathrm{Cl}}$ is $+70 \mathrm{mV}$. LPA elicited an inward current. $d, V_{\text {rev }}$ for the response in $c$ is $+55 \mathrm{mV}$, consistent with a chloride conductance in low- $\mathrm{Cl}^{-}$saline. $e$, LPA exposure in the embryonic cortical cell line TSM stably overexpressing $l p_{\mathrm{A} 1} / v z g-1$ also showed LPAdependent inward currents (compare $a$ ). $f, V_{\text {rev }}$ for the response in $e$ is $-29 \mathrm{mV}$, consistent with a $\mathrm{Cl}^{-}$conductance (compare $b$ ). opment and preceded both GABA and L-glutamate sensitivity that appeared at subsequent ages. A majority of cells examined were LPA-responsive, consistent with a prominent role for this lysophospholipid in cortical development.

Examined cells were identified as early cortical neuroblasts based on multiple criteria. At the ages of cell isolation, E11-E12, very few neurons have become postmitotic, and few glia appear to be generated (Caviness, 1982; Blaschke et al., 1996, 1998; Weiner and Chun, 1997). The examined cells could also be easily distinguished by their spherical shape and association in clusters, contrasting with rare, flat, fibroblast-like cells that were also present in the culture. The presence of extensive electrical coupling within the examined clusters is the normal, physiological state of cells in the VZ (LoTurco and Kriegstein, 1991), and the resting membrane potential of these cells was consistent with previous measurements of cortical neuroblasts within living tissue slices (LoT urco et al., 1995). At the older ages examined, 12-20 hr after isolation at E12 (E12-E13), prominent GABA responses were also observed in the spherical cells, further consistent with previous observations on cortical neuroblasts (LoTurco and Kriegstein, 1991; LoTurco et al., 1995). Cells responding to LPA were also nestin-immunoreactive which, combined with the aforemen- tioned criteria, is again consistent with a neuroblast identity (Cataneo and McKay, 1990). In addition, the high percentage of cells responding to LPA ( $>60 \%$ at E11; see Table 2$)$ was consistent with the extent of $l p_{\mathrm{A} 1} / v z g-1$ expression in the $\mathrm{VZ}$ observed by in situ hybridization at comparable ages, where most cells appeared to express this LPA receptor gene (Hecht et al., 1996). Moreover, the electrical properties and LPA-dependent $G_{\mathrm{C} 1}$ changes of the putative neuroblasts were similar to those of neuroblast cell lines derived from the embryonic cortex (Chun and Jaenisch, 1996) in which single (noncoupled) cells were examined, indicating that electrical coupling per se was not necessary for the observed physiological responses. Taken together, these data show that the examined primary cells possess developmental and phenotypic characteristics of cortical neuroblasts while responding to LPA stimulation.

LPA exposure induced responses that cannot be explained by nonspecific or known secondary effects. Nonspecific effects could hypothetically be produced by detergent properties of LPA through micelle formation, but such effects are not seen until the critical micelle concentration is reached $(>1 \mathrm{~mm}$ ) (Durieux, 1995), whereas all of our studies were performed in the nanomolar concentration range. In addition, a structurally similar ligand 
a

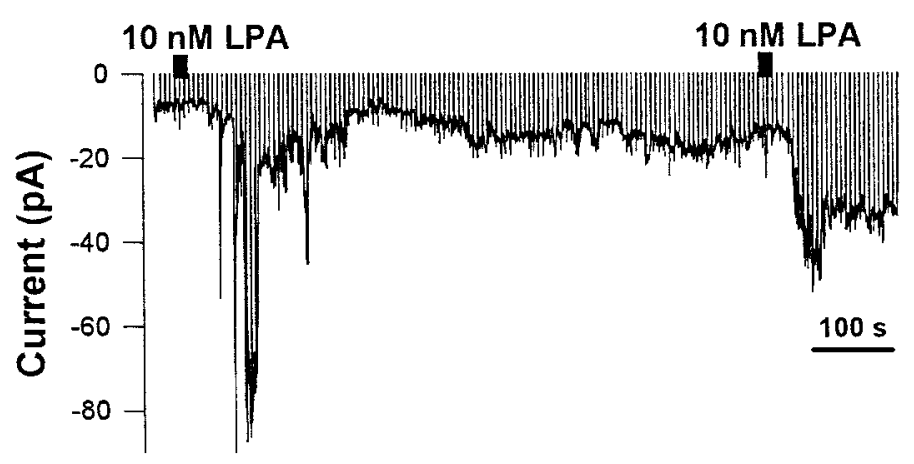

C

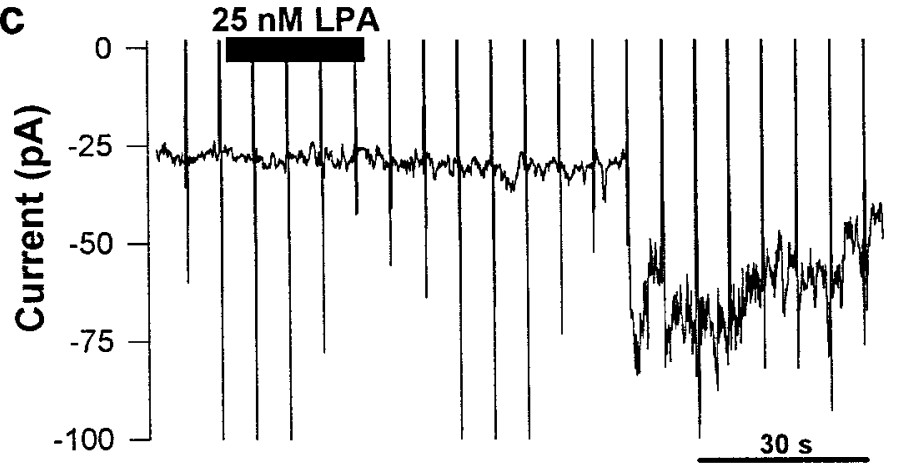

b
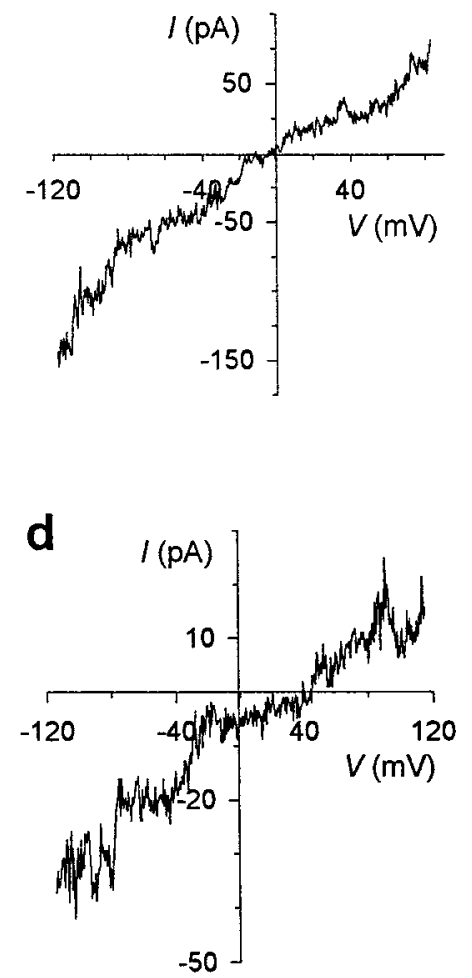

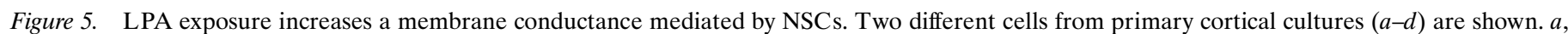

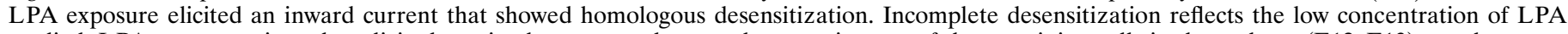

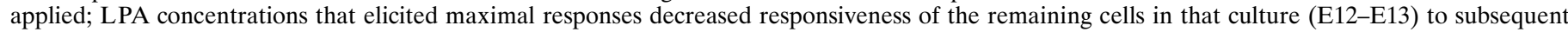

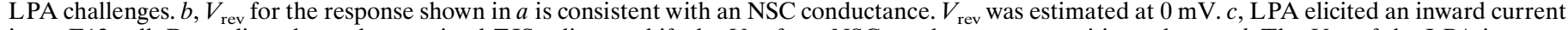

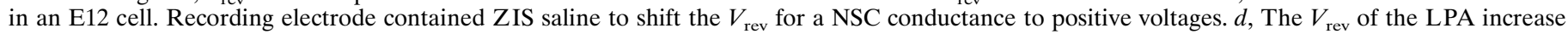
in conductance shown in $c$ was $+46 \mathrm{mV}$ (ZIS/Tyrode's).

having potential detergent properties, LPG, did not elicit these responses (Fig. 4a). We examined the membrane for possible damage by LPA by monitoring the reversal potential after LPA exposure; these studies demonstrated an intact membrane (Fig. $5 c, d)$. Moreover, if the conductance changes were a nonspecific perturbation, all cells should respond, and the response should be stereotyped. In fact, $\sim 1 / 3$ of the cells did not respond at all (Table 2). Similarly, as seen in Figure $6 c$, application of LPA after stimulation of a cell by GABA/L-glutamate produced no conductance changes, again inconsistent with a lack of specificity. Combined, these data argue against nonspecific activation of conductance changes by LPA.

Another possibility is that GABA or L-glutamate could produce the conductance changes as a secondarily released factor. This explanation is inconsistent with the previous literature and our data. Based on studies by Kriegstein (LoTurco et al., 1995) in which GABA responses among embryonic VZ cells were extensively characterized, only $\mathrm{GABA}_{\mathrm{A}}$ responses were observed, i.e., the fast, ligand-gated ion channel responses, whereas $\mathrm{GABA}_{\mathrm{B}}$ responses were not observed in any of these VZ cells, and our data confirm this observation. Similarly, L-Glu responses were also mediated by ligand-gated ion channels. We observed both $\mathrm{GABA}_{\mathrm{A}}$ and ionotropic L-Glu receptor responses, both of which have a relatively brief latency (Fig. 6). This brief latency fundamentally contrasts with the prolonged latency of LPA responses, $30-45 \mathrm{sec}$, that is nearly identical to LPA latencies observed in two different cell systems (Holtsberg et al., 1997; Thoreson et al., 1997). Migrating, postmitotic cortical cells have been reported to respond through $\mathrm{GABA}_{\mathrm{B}}$ receptors (Behar et al., 1996), however $\mathrm{GABA}_{\mathrm{B}}$-type responses were not reported in $\mathrm{VZ}$ cells of previous studies (LoTurco et al., 1995) and in the present study, never seen even in the presence of clearly detectable $\mathrm{GABA}_{\mathrm{A}}$ responses (demonstrating that GABA was active); these data are compatible with $\mathrm{GABA}_{\mathrm{B}}$ receptors being expressed on at least some newly postmitotic neurons, but not being expressed on mitotic neuroblasts that are electrically coupled in the cell clusters that were recorded here. In addition, no GABA responses (fast or slow) were ever observed at E11. Still further, the increase in chloride conductance with a latency of $30 \mathrm{sec}$ is not typical for a $\mathrm{GABA}_{\mathrm{B}}$ receptor (which generally reduces calcium, and increases potassium conductances) (Rang et al., 1995). The direct experimental paradigm of exposing a cell to GABA/L-Glu followed by LPA, or vice-versa (Fig. 6) again illustrates that secondary phenomena cannot account for the LPA responses. Our combined experimental data along with the previous literature show that the responses we observe cannot be explained by secondary release of the previously identified factors, GABA or L-glutamate.

LPA activated two distinct conductances in separate populations of cells. Half of the responsive cells showed increased $\mathrm{Cl}^{-}$ conductance based on reversal potential and ion substitution experiments. LPA has been reported to increase $\mathrm{Cl}^{-}$conductances in non-neuronal cells, including defolliculated Xenopus oocytes (Durieux et al., 1992; Fernhout et al., 1992), wounded corneal keratocytes (Watsky, 1995), and quiescent Rat-1 fibroblasts (Fischer et al., 1995). There are differences in observed responses that include homologous desensitization, apparent li- 

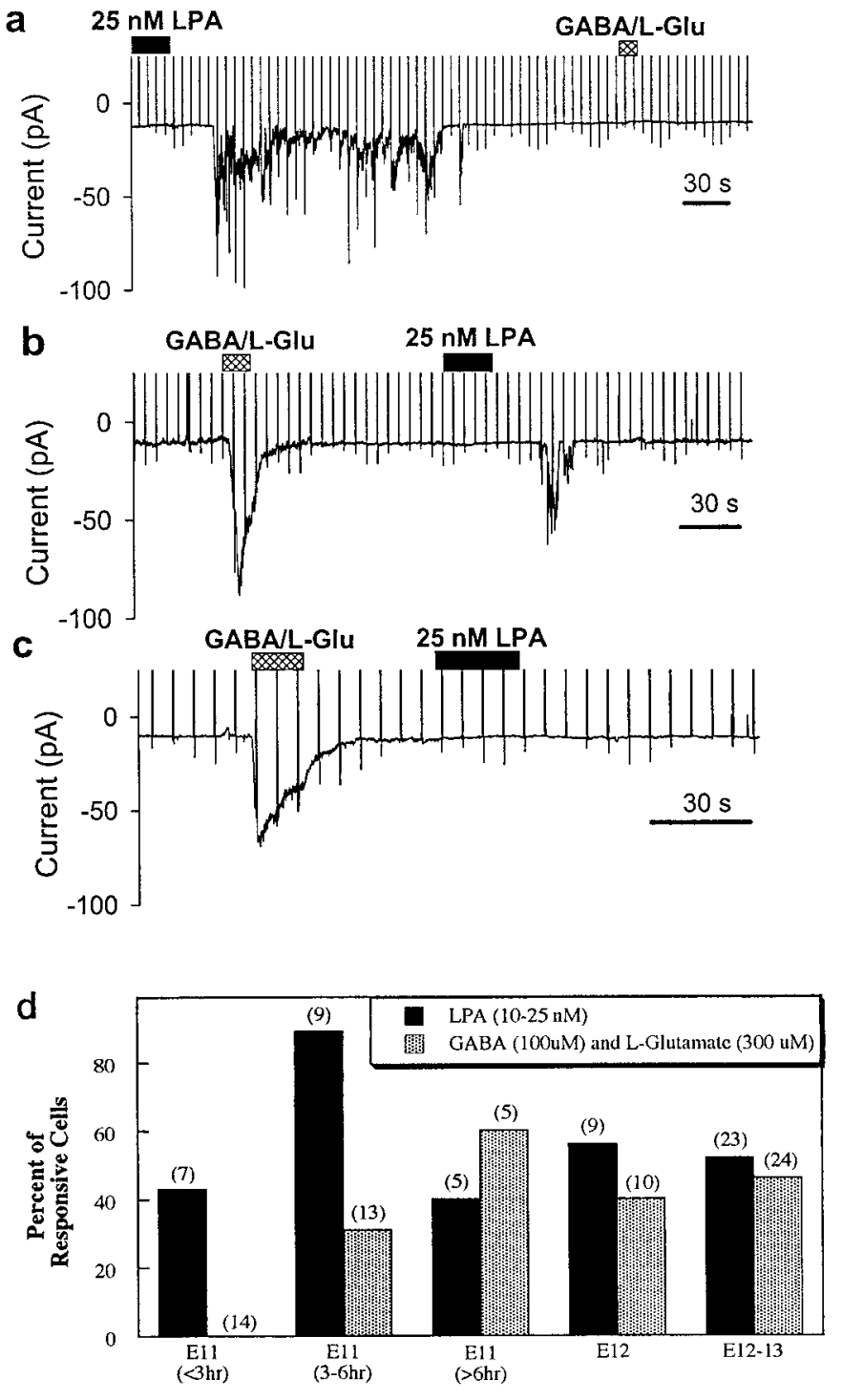

Figure 6. LPA responsiveness precedes that of GABA or L-glutamate in early cortical neuroblasts. E11-E12 cortices were dissociated, plated onto glass coverslips, and examined at the indicated times using whole-cell recording techniques for sensitivity to puffer application of LPA and combined GABA/L-glutamate. Solid bars indicate duration of LPA exposure, and hatched bars indicate GABA/L-glutamate exposure. $a$, Representative recording from an E11 neuroblast responding to LPA only. The $V_{\text {rev }}$ for this response was $-40 \mathrm{mV}$, consistent with an increase in $\mathrm{Cl}^{-}$ conductance (1.05 nS). $b$, An E12 neuroblast sensitive to both LPA and GABA/L-glutamate. LPA responses, $V_{\text {rev }}$ was $-14 \mathrm{mV}$ (NSC); increase in conductance was at least $800 \mathrm{pS}$. GABA response: $V_{\text {rev }}$ was $-34 \mathrm{mV}$ (consistent with being mediated by $\mathrm{Cl}^{-}$and not NSC); increase in conductance was at least $1530 \mathrm{pS}$. $c$, An E12 neuroblast responsive to only GABA. The response to the GABA/L-glutamate application reversed at $-45 \mathrm{mV}$ consistent with its being mediated by $\mathrm{GABA}_{\mathrm{A}}$ receptors; the increase in conductance was at least $2 \mathrm{nS}$. $d$, Developmental onset of ligand sensitivity. Solid bars indicate LPA responsiveness; stippled bars indicate $\mathrm{GABA} / \mathrm{L}$-glutamate responsiveness. During the first $3 \mathrm{hr}$ after plating E11 cortices, only LPA sensitivity was observed, representing $\sim 50 \%$ of recorded cells (the remainder being unresponsive). By E12, neuroblasts began responding to both LPA and GABA/L-glutamate. By E12-E13 (cells isolated at E12 and cultured for 12-20 hr), approximately equal percentages of cells responded to either LPA or GABA/L-glutamate. gand affinity, pertussis toxin sensitivity, and $\mathrm{Ca}^{2+}$ sensitivity. These likely reflect differences in cell type, lysophospholipid (including LPA) receptors (Hecht et al., 1996; Fukushima et al., 1998; Chun et al., 1999; Zhang et al., 1999), and/or downstream mechanisms. The mechanisms underlying activation of the LPAinduced $\mathrm{Cl}^{-}$conductance in cortical neuroblasts are under investigation. One possibility involves increases in intracellular $\mathrm{Ca}^{2+}$ and subsequent activation of $\mathrm{Ca}^{2+}$-activated $\mathrm{Cl}^{-}$channels. LPA increases intracellular $\mathrm{Ca}^{2+}$ in some neuroblasts in these primary cultures (Fluo-3 and Fura-2 imaging; A. Dubin, T. Bahnson, and J. Chun, unpublished observation). Alternatively, $\mathrm{Cl}^{-}$ currents may be activated by cytoskeletal remodeling. Alterations in the actin cytoskeleton have been shown to gate $\mathrm{Cl}^{-}$channels in neocortical astrocytes (Lascola et al., 1998), embryonic human skeletal muscle myoballs (Häussler et al., 1994), and human vascular endothelial cells (Oike et al., 1994). Actin depolymerization opens $\mathrm{CFTR} \mathrm{Cl}^{-}$channels with a time course similar to that observed after LPA stimulation (Fischer et al., 1995). Rearrangements of the actin cytoskeleton could provide such a mechanism and are consistent with LPA-dependent cell-rounding observed in neuroblast cell lines (Jalink et al., 1994; Hecht et al., 1996; Fukushima et al., 1998; Chun et al., 1999).

An NSC conductance rather than a $\mathrm{Cl}^{-}$conductance was activated by LPA in a second population of cells. $\mathrm{Ca}^{2+}$ may permeate the LPA-activated channels underlying this NSC response, and its contribution to the inward current may be considerable (Frings et al., 1995). NSC conductances that allow $\mathrm{Ca}^{2+}$ entry could participate in the extensive programmed cell death among cortical neuroblasts within the VZ (Blaschke et al., 1996, 1998; Staley et al., 1997) and could also lead to some of the myriad effects associated with $\mathrm{Ca}^{2+}$ signaling.

The conductance changes produced by LPA in neuroblasts are likely to be depolarizing. The $\mathrm{Cl}^{-}$equilibrium potential has been shown to be approximately $-30 \mathrm{mV}$ in rat neuroblasts using gramicidin perforated-patch techniques (Owens et al., 1996), and NSC conductances have reversal potentials near $0 \mathrm{mV}$. Thus, LPA-dependent increases in NSC as well as $\mathrm{Cl}^{-}$conductances would produce a depolarization. There were no detectable differences in resting physiological properties between cells responding to LPA with an increased $\mathrm{Cl}^{-}$or NSC conductance. The resting membrane potentials, magnitudes of $I_{\mathrm{Na}}$ and outward current densities, $C_{\mathrm{m}}$, and $R_{\mathrm{m}}$ were not significantly different. The biological significance of these distinct ionic groups awaits further investigation. Their existence, however, provides a potential link between LPA signaling and several outcomes known to occur within the VZ: cell proliferation, differentiation, and death. In addition to the relatively rapid effects, seconds to minutes, documented here, LPA also has longer term growth factor-like properties in other systems that are manifest over a period of hours to days (Moolenaar et al., 1992). These comparatively long-term effects complement the LPA-dependent responses observed. We note that this scenario is undoubtedly incomplete, and it will be crucial to determine which of these LPA effects take place in vivo through genetic and cell biological strategies. Regardless of the actual roles of the ionic conductance responses observed here, it is notable that they resemble neurotransmitter stimulation among neuroblasts at an early developmental stage that precedes GABA and/or L-glutamate responsiveness, thus providing an additional mechanism for producing ionic conductance changes at the earliest stages of cortical neurogenesis.

The existence of G-protein-coupled receptor-mediated LPA signaling in the embryonic cortex adds to receptor tyrosine kinase 
and neurotransmitter-gated ion channels as a new and potentially important ligand-receptor system influencing cerebral cortical neurogenesis. A difficult but important issue to address is the in vivo cellular source of extracellular LPA. Because LPA is also produced intracellularly as an intermediate in phospholipid biosynthesis (Durieux, 1995), this source must be differentiated from the pool that acts as an extracellular signal. The presented data indicate that the stimulatory activity of LPA affects the majority of cortical neuroblasts, consistent with the spatial and temporal expression of the LPA receptor gene $l p_{\mathrm{A} 1} / v z g-1$ (Jalink et al., 1994; Hecht et al., 1996; Fukushima et al., 1998; Chun et al., 1999). As the first electrophysiological evidence of extracellular lysophospholipid signaling during CNS development, these data indicate that LPA, along with other related lipid molecules and their cognate receptors, could have important influences on the development and function of the cerebral cortex as well as other parts of the nervous system.

\section{REFERENCES}

Angevine JB, Sidman RL (1961) Autoradiographic study of cell migration during histogenesis of cerebral cortex in the mouse. Nature 192:766-768.

Armstrong CM, Gilly WF (1992) Access resistance and space clamp problems associated with whole-cell patch clamping. Methods Enzymol 207:100-122.

Barry PH (1994) JPCalc, a software package for calculating liquid junction potential corrections in patch-clamp, intracellular, epithelial and bilayer measurements and for correcting junction potential measurements. J Neurosci Methods 51:107-116.

Behar TN, Li YX, Tran HT, Ma W, Dunlap V, Scott C, Barker JL (1996) GABA stimulates chemotaxis and chemokinesis of embryonic cortical neurons via calcium-dependent mechanisms. J Neurosci 16:1808-1818.

Bittman K, Owens DF, Kriegstein AR, LoTurco JJ (1997) Cell coupling and uncoupling in the ventricular zone of developing neocortex. J Neurosci 17:7037-7044.

Blaschke AJ, Staley K, Chun J (1996) Widespread programmed cell death in proliferative and postmitotic regions of the fetal cerebral cortex. Development 122:1165-1174.

Blaschke AJ, Weiner JA, Chun J (1998) Programmed cell death is a universal feature of neuroproliferative regions throughout the developing CNS. J Comp Neurol 396:39-50.

Boulder Committee (1970) Embryonic vertebrate central nervous system: revised terminology. Anat Rec 166:257-261.

Cataneo E, McKay R (1990) Proliferation and differentiation of neuronal stem cells regulated by nerve growth factor. Nature 347:762-765.

Caviness VSJ (1982) Neocortical histogenesis in normal and reeler mice: a developmental study based upon $\left[{ }^{3} \mathrm{H}\right.$-thymidine autoradiography. Dev Brain Res 4:293-302.

Chun J, Jaenisch R (1996) Clonal cell lines produced by infection of neocortical neuroblasts using multiple oncogenes transduced by retroviruses. Mol Cell Neurosci 7:304-321.

Chun JJM, Nakamura MJ, Shatz CJ (1987) Transient cells of the developing mammalian telencephalon are peptide-immunoreactive neurons. Nature 325:617-620.

Chun J, Contos JJA, Munroe D (1999) A growing family of receptor genes for lysophosphatidic acid (LPA) and other lysophospholipids (LPs). Cell Biochem Biophys, in press.

de Roos AD, van Zoelen EJ, Theuvenet AP (1996) Determination of gap junctional intercellular communication by capacitance measurements. Pflügers Arch 431:556-563.

Delay RJ, Dubin AE, Dionne VE (1997) A cyclic nucleotide-dependent chloride conductance in olfactory receptor neurons. J Membr Biol 159:53-60.

Dubin AE, Dionne VE (1994) Action potentials and chemosensitive conductances in the dendrites of olfactory neurons suggest new features for odor transduction. J Gen Physiol 103:181-201.

Durieux ME (1995) Lysophosphatidate signaling. Austin, TX: R. G. Landes.

Durieux ME, Salafranca MN, Lynch KR, Moorman JR (1992) Lysophosphatidic acid induces a pertussis toxin-sensitive $\mathrm{Ca}(2+)$-activated $\mathrm{Cl}^{-}$current in Xenopus laevis oocytes. Am J Physiol 263:C896-C900.
Ernfors P, Lee KF, Jaenisch R (1994) Mice lacking brain-derived neurotrophic factor develop with sensory deficits. Nature 368:147-150.

Fariñas I, Jones KR, Backus C, Wang XY, Reichardt LF (1994) Severe sensory and sympathetic deficits in mice lacking neurotrophin-3. Nature 369:658-661.

Fernhout BJ, Dijcks FA, Moolenaar WH, Ruigt GS (1992) Lysophosphatidic acid induces inward currents in Xenopus laevis oocytes; evidence for an extracellular site of action. Eur J Pharmacol 213:313-315.

Fischer H, Illek B, Machen TE (1995) The actin filament disrupter cytochalasin D activates the recombinant cystic fibrosis transmembrane conductance regulator $\mathrm{Cl}^{-}$channel in mouse 3T3 fibroblasts. J Physiol (Lond) 489:745-754.

Frings S, Seifert R, Godde M, Kaupp UB (1995) Profoundly different calcium permeation and blockage determine the specific function of distinct cyclic nucleotide-gated channels. Neuron 15:169-179.

Fukushima N, Kimura Y, Chun J (1998) A single receptor encoded by vzg-1/lpA1/edg-2 couples to G-proteins and mediates multiple cellular responses to lysophosphatidic acid. Proc Natl Acad Sci USA 95:6151-6156.

Ghosh A, Greenberg ME (1995) Distinct roles for bFGF and NT-3 in the regulation of cortical neurogenesis. Neuron 15:89-103.

Hamill OP, Marty A, Neher E, Sakmann B, Sigworth FJ (1981) Improved patch-clamp techniques for high-resolution current recording from cells and cell-free membrane patches. Pflügers Arch 391:85-100.

Hancock AA, Bush EN, Stanisic D, Kyncl JJ, Lin CT (1988) Data normalization before statistical analysis: keeping the horse before the cart. Trends Pharmacol Sci 9:29-32.

Häussler U, Rivet-Bastide M, Fahlke C, Müller D, Zachar E, Rüdel R (1994) Role of the cytoskeleton in the regulation of $\mathrm{Cl}^{-}$channels in human embryonic skeletal muscle cells. Pflügers Arch 428:323-330.

Hecht JH, Weiner JA, Post SR, Chun J (1996) Ventricular zone gene-1 (vzg-1) encodes a lysophosphatidic acid receptor expressed in neurogenic regions of the developing cerebral cortex. J Cell Biol 135:1071-1083.

Hill CS, Oh SY, Schmidt SA, Clark KJ, Murray AW (1994) Lysophosphatidic acid inhibits gap-junctional communication and stimulates phosphorylation of connexin-43 in WB cells: possible involvement of the mitogen-activated protein kinase cascade. Biochem J 303:475-479.

Holtsberg FW, Steiner MR, Furukawa K, Keller JN, Mattson MP, Steiner SM (1997) Lysophosphatidic acid induces a sustained elevation of neuronal intracellular calcium. J Neurochem 69:68-75.

Jalink K, van Corven EJ, Hengeveld T, Morii N, Narumiya S, Moolenaar WH (1994) Inhibition of lysophosphatidate- and thrombin-induced neurite retraction and neuronal cell rounding by ADP ribosylation of the small GTP-binding protein Rho. J Cell Biol 126:801-810.

Kilpatrick TJ, Bartlett PF (1993) Cloning and growth of multipotential neural precursors: requirements for proliferation and differentiation. Neuron 10:255-265.

Klein R, Smeyne RJ, Wurst W, Long LK, Auerbach BA, Joyner AL, Barbacid M (1993) Targeted disruption of the trkB neurotrophin receptor gene results in nervous system lesions and neonatal death. Cell 75:113-122.

Klein R, Silos-Santiago I, Smeyne RJ, Lira SA, Brambilla R, Bryant S, Zhang L, Snider WD, Barbacid M (1994) Disruption of the neurotrophin-3 receptor gene trkC eliminates la muscle afferents and results in abnormal movements. Nature 368:249-251.

Lascola CD, Nelson DJ, Kraig RP (1998) Cytoskeletal actin gates a Clchannel in neocortical astrocytes. J Neurosci 18:1679-92.

LoTurco JJ, Kriegstein AR (1991) Clusters of coupled neuroblasts in embryonic neocortex. Science 252:563-566.

LoTurco JJ, Blanton MG, Kriegstein AR (1991) Initial expression and endogenous activation of NMDA channels in early neocortical development. J Neurosci 11:792-799.

LoTurco JJ, Owens DF, Heath MJ, Davis MB, Kriegstein AR (1995) GABA and glutamate depolarize cortical progenitor cells and inhibit DNA synthesis. Neuron 15:1287-1298.

Moolenaar WH (1995) Lysophosphatidic acid signalling. Curr Opin Cell Biol 7:203-210.

Moolenaar WH, Jalink K, van Corven EJ (1992) Lysophosphatidic acid: a bioactive phospholipid with growth factor-like properties. Rev Physiol Biochem Pharmacol 119:47-65.

Oike M, Schwarz G, Sehrer J, Jost M, Gerke V, Weber K, Droogmans G, Nilius B (1994) Cytoskeletal modulation of the response to mechanical stimulation in human vascular endothelial cells. Pflügers Arch 428:569-576. 
Owens DF, Boyce LH, Davis MB, Kriegstein AR (1996) Excitatory GABA responses in embryonic and neonatal cortical slices demonstrated by gramicidin perforated-patch recordings and calcium imaging. J Neurosci 16:6414-6423.

Postma FR, Jalink K, Hengeveld T, Bot AG, Alblas J, de Jonge HR, Moolenaar WH (1996) Serum-induced membrane depolarization in quiescent fibroblasts: activation of a chloride conductance through the G protein-coupled LPA receptor. EMBO J 15:63-72.

Rang HP, Dale MM, Ritter JM, Gardner P (1995) Pharmacology. Edinburgh: Churchill Livingstone.

Smeyne RJ, Klein R, Schnapp A, Long LK, Bryant S, Lewin A, Lira SA, Barbacid M (1994) Severe sensory and sympathetic neuropathies in mice carrying a disrupted Trk/NGF receptor gene. Nature 368:246-249.

Staley K, Blaschke AJ, Chun JJM (1997) Apoptotic DNA fragmentation is detected by a semi-quantitative ligation-mediated PCR of blunt DNA ends. Cell Death and Differentiation 4:66-75.
Temple S, Davis AA (1994) Isolated rat cortical progenitor cells are maintained in division in vitro by membrane-associated factors. Development 120:999-1008.

Temple S, Qian X (1995) bFGF, neurotrophins, and the control or cortical neurogenesis. Neuron 15:249-252.

Thoreson WB, Khandalavala BN, Manahan RG, Polyak IA, Liu JL, Chacko DM (1997) Lysophosphatidic acid stimulates proliferation of human retinal pigment epithelial cells. Curr Eye Res 16:698-702.

Watsky MA (1995) Lysophosphatidic acid, serum, and hyposmolarity activate $\mathrm{Cl}^{-}$currents in corneal keratocytes. Am J Physiol 269:C1385-C1393.

Weiner JA, Chun J (1997) Png-1, a nervous system-specific zinc finger gene, identifies regions containing postmitotic neurons during mammalian embryonic development. J Comp Neurol 381:130-142.

Zhang G, Contos JJA, Weiner JA, Fukushima N, Chun J (1999) Comparative analysis of three murine G-protein coupled receptors activated by sphingosine-1-phosphate. Gene, in press. 